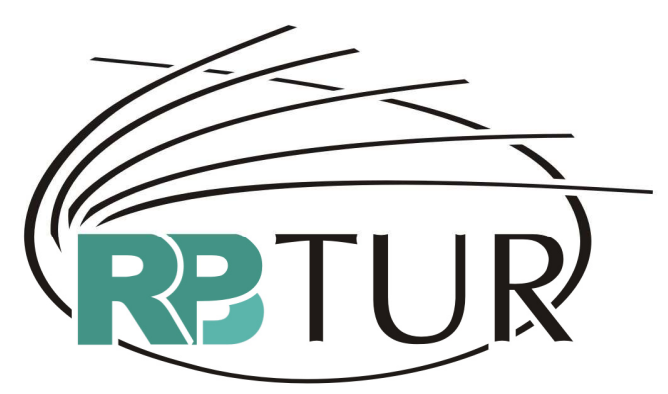

REVISTA BRASILEIRA DE PESQUISA EM TURISMO

\title{
EDITORIAL
}

\section{EDITORS PAGE}

Neste último número do ano de 2008 em primeiro lugar queremos agradecer a todas aquelas pessoas que contribuiram e contribuem com a edição desta revista eletrônica e desejar que todos tenhamos um ano 2009 pleno de realizações profissionais e pessoais.

Os artigos que aqui apresentamos refletem pesquisas em vários temas relacionados ao turismo: ensino, economia, novas tendências de mercado, patrimônio. Todos trazem visões diferentes e até antagônicas, mostrando a complexidade deste fenômeno ou fato social que está, de fato, pleno de contradições.

Em relação ao tema ensino, Francisco José da Costa apresenta um estudo sobre o interesse dos alunos dos cursos de turismo da cidade de Fortaleza (CE) em empreender atividades empresariais após a formatura. 0 autor descobre que o discurso da academia quanto ao empreendedorismo tem um eco relativo e que o empreendedorismo interessa mais aos estudantes que têm propensão natural para ele ou que provêm de famílias empreendedoras. Embora se trate de um estudo com poucos casos, circunscrito a uma capital, portanto não passível de generalização, pode ser indicativo de uma tendência, que deveria alertar para os demais cursos do país, fundamentalmente aqueles que alicerçam seus programas na formação para o empreendedorismo.

Enquanto os cursos de turismo continuam tentando estimular novos empresários e formando recursos humanos para o planejamento do turismo, o poder público parece não despertar para a necessidade do mesmo, nem os empresários que têm dinheiro para abrir seus próprios negócios. É o que discute Roque Pinto num estudo de caso em Ilhéus, na BA. Este município que 
fora extremadamente rico durante o auge da monocultura do cacau, muito conhecido através da literatura e da pessoa de Jorge Amado (1912-2001), passou a ter um crescimento espontâneo do turismo, mas sem planejamento nem público nem privado. O estado não cuida da infra-estrutura e o empresariado atua na área de turismo enquanto espera o retorno das benesses do cacau, ou como passatempo enquanto desfruta da aposentadoria numa cidade tranquila perto do mar. Para o autor, o problema principal é que nem estes empresários nem o estado enxergam o turismo como possibilidade econômica

Paradoxalmente, Mónica Lacarrieu que é antropóloga tal qual Roque Pinto, enfatiza, no seu artigo, que o problema do turismo tem sido o contrário: ser visto apenas como um fator econômico. A autora discorre sobre a necessidade de ver a relação entre turismo e política, no que traz uma inovação importante nos estudos realizados não apenas na América do Sul mas também do mundo, desde que são poucos os trabalhos fora os de Linda Richter, que focalizam a tal relação. Apresentando o caso de Buenos Aires, Lacarrieu analisa a utilização turística de estereótipos históricos pasteurizados que mascaram os problemas sociais e dos problemas sociais em si mesmos, tais como a pobreza recentemente instalada pelo projeto neoliberal do ex presidente Menem, e o protesto político muitas vezes dirigida a partir outros centros de poder.

Como podem duas pessoas com a mesma formação e com o mesmo respaldo teórico oferecem duas explicações antagônicas? Podem, desde que o turismo não têm as mesmas características nem o mesmo desempenho nem obedece aos mesmos fatores em todos os lugares. É, como vimos afirmando há vários anos, um fenômeno rizomático o que tem tornado tão difícil haver um corpo de teorias a alicerçar os estudos, ou, dito de outra forma, a construção de teorias sobre o turismo.

Dentro da rubrica produtos e serviços, o artigo de Kushano e Almeida mostra a triste realidade quanto à contradição entre prática e discurso, assim como a limitação de determinados conceitos ou do entendimento dos mesmos. 
Analisando a adaptação da hotelaria para portadores de necessidades especiais, descobrem que os portadores de deficiência auditiva estão muito pouco ou quase nada contemplados na hotelaria. Embora também se trate de um estudo de caso restrito à cidade de Curitiba (PR) a evidência empírica permite sugerir uma tendência no restante do país e, por que não, do cone sul, problema que também se verifica na área da cultura em geral e da educação.

Finalmente, mostrando outro paradoxo do turismo, Berdasco, Afonso e Medeiros, sob orientação de Rejowski, investigam que, na cidade de São Paulo (SP), muitos hotéis se aparelham e muito bem para atender cães e gatos, sozinhos ou com seus donos. As autoras também alertam para o fato de que não é possível fazer generalizações e transparece no texto que tampouco a humanização dos animais é exclusiva do turismo. Os animais de estimação vêm ganhando cada vez mais espaço, no mercado de consumo assim como nos lares, face à crescente solidão em que vivem as pessoas no mundo contemporâneo, questão sobre a qual as autoras conclamam a refletir.

A presente edição fecha com a crônica do evento anual da ANPTUR que esta vez aconteceu na cidade de Belo Horizonte, escrita pela presidente da associação, Mirian Rejowski e com a resenha de um livro pouco conhecido ainda no Brasil, The business of Tourism Management, na qual os leitores poderão ter, em oito páginas, um resumo de quase seiscentas, feito com maestria por Alexandre Panosso Netto.

Margarita Barretto Sênia Bastos Editoras 